\title{
Total synthesis of dehydro-boscialin glucoside
}

\author{
Karsten Krohn* and Attila Agocs \\ Department of Chemistry, University of Paderborn, Warburger Str. 100, 33098 Paderborn, \\ Germany \\ E-mail: karsten.krohn@uni-paderborn.de
}

Dedicated to Professor Dr. Dr. h.c. Lutz Friedjan Tietze on the occasion of his $65^{\text {th }}$ birthday

\begin{abstract}
2',3'-Dehydro-boscialin glucopyranoside (6) (mixture of diastereoisomers) was synthesized by Königs-Knorr glycosylation of racemic 2,3-dehydroboscialin with acetobromoglucose and silver carbonate as the catalyst followed by Zemplén deacetylation. The requisite 2,3-dehydroboscialin was available selectively as a (Z)-diol from dehydro- $\beta$-ionone (3) by photooxidation and reduction.
\end{abstract}

Keywords: 2',3'-Dehydro-boscialin glucopyranoside, photooxidation, thiourea reduction, Königs-Knorr glycosylation

\section{Introduction}

Boscialin, a natural product structurally related to ionones, was first isolated by Séquin et al. ${ }^{1}$ from the leaves of the African tree Boscia salicifolia Oliv.. The extracts of these leaves are used in traditional medicine because of their antibacterial and antifungal activity. Later, related boscialin glucosides were isolated from leaves of Pterospermum acerifolium, a plant growing in Bangladesh, India, and Pakistan. ${ }^{2}$ The authors reported that 4'-O- $\beta$-D-glucopyranoside-boscialin (1) (Scheme 1) showed significant insulin releasing effect on isolated rat pancreatic islets. Considering the increasing worldwide demand for new insulin releasing drugs in the treatment of diabetes type II, we initiated a program for a short and efficient synthesis of boscialin glycosides and related compounds for tests of insulin releasing activity.

The first total synthesis of boscialin (the aglycone of compound 1) and its epimer by Séquin et $a l .{ }^{3}$ started from (R)-2,2,6-trimethyl-1,4-cyclohexanedione. One of the problems in this multistep synthesis was the stereoselective construction of the 1',4'-cis-diol arrangement of the boscialin molecule. In our synthetic scheme, we anticipated that photooxidation of dehydro- $\beta$ ionone (3) might generate the cis-diol after reduction of the intermediate endoperoxide. In addition, this starting material already contained the correct placement of all of the methyl 
groups and the side chain at $\mathrm{C}-1$ '. A literature survey revealed that both the NBS mediated dehydrogenation ${ }^{4}$ of $\beta$-ionone (2) to dehydro- $\beta$-ionone (3), as well as the photooxidation of (3) and the subsequent reduction ${ }^{5}$ to the cis-diol (4) were described, encouraging the execution of the synthesis of dehydroboscialin glycoside (6) using this simple route.

\section{Results and Discussion}

We now disclose a short and efficient synthesis of dehydro-boscialin glucoside (6) (Scheme 1) presenting a straightforward solution for appropriate 1,4-cis diol generation. $\beta$-Ionone (2) was halogenated with NBS and treated with base to afford dehydro- $\beta$-ionone (3). ${ }^{4}$ A solution of the diene 3 in methanol was irradiated under an atmosphere of oxygen containing Rose Bengal as sensitizer and the resulting intermediate endoperoxide was reduced with thiourea to yield the racemic 2,3-dehydro-boscialin (4). ${ }^{5}$ To obtain the closely related, but not naturally occurring, 2',3'-dehydro derivative $\mathbf{6}$ of the natural product 1, the dehydro-boscialin (4) was glycosylated under Königs-Knorr conditions using silver carbonate as the catalyst, to afford the tetraacetate 5 as an inseparable 1:1 mixture of diastereoisomers (only one of the diastereomers is shown in Scheme 1).
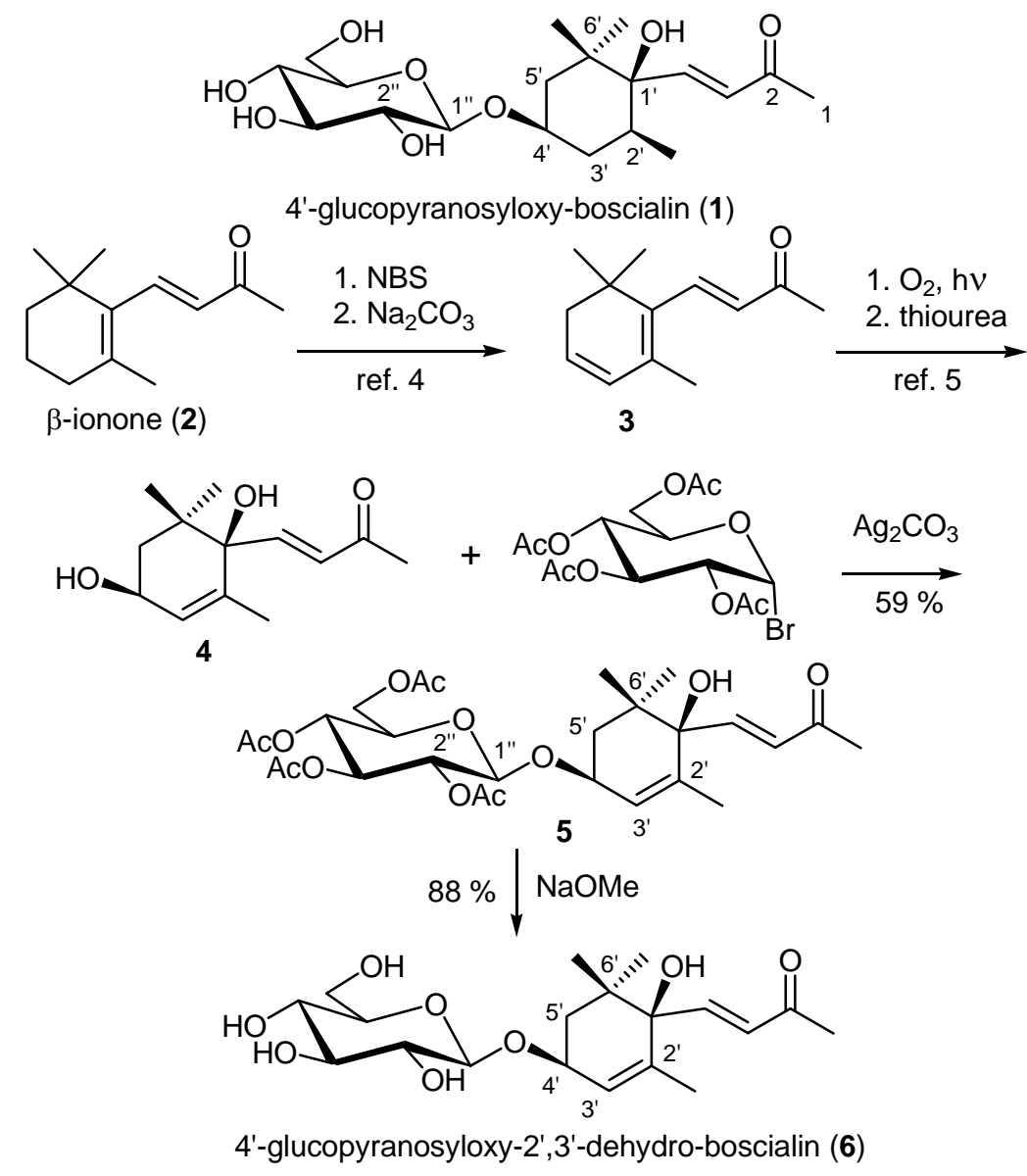

\section{Scheme 1}


Some of the resonances in the NMR spectra of the diastereomeric mixture of 5 appeared as two signals, but the $\beta$-glucoside nature was clearly established by the coupling constants of $J_{1 ", 2 "}$ $=9.5 \mathrm{~Hz}$ for the anomeric protons. Finally, the tetraacetate 5 was deprotected by treatment with catalytic amounts of $\mathrm{NaOMe}$ in methanol to afford the unstable 4'-glucopyranosyloxy-2',3'dehydro-boscialin (6). The insulin-releasing effect of the 2',3'-dehydro-boscialin glucopyranoside (6) is presently under investigation.

\section{Experimental Section}

For general methods and instrumentation see ref. 7.

E-[4'-[(Tetra-O-acetyl- $\beta$-D-glucopyranosyl)oxy]-1'-hydroxy-2',6',6'-trimethylcyclohex-2enyl]but-3-en-2-one (5) (mixture of diastereoisomers). A solution of dehydro-boscialin (4) ${ }^{5}$ $(0.85 \mathrm{~g}, 3.8 \mathrm{mmol})$ in dry dichloromethane $(50 \mathrm{ml})$ was treated with $4 \AA$ molecular sieves $(5 \mathrm{~g})$, acetobromoglucose $(2.85 \mathrm{~g}, 6.75 \mathrm{mmol})$ and silver carbonate $(5.6 \mathrm{~g}, 20 \mathrm{mmol})$. The mixture was stirred at room temperature for four days. The suspension was then filtered through Celite and evaporated. Column chromatography on silica gel (hexane: ethyl acetate, $1: 1$ ) resulted in $1.25 \mathrm{~g}$ $(59 \%)$ of a foamy solid from the fraction of intermediate polarity. IR: $v\left(\mathrm{~cm}^{-1}\right)=3488,2924$, 2847, 1750, 1377, 1222, 1041. ${ }^{1} \mathrm{H}-\mathrm{NMR}\left(\mathrm{CDCl}_{3}, 200 \mathrm{MHz}\right): \delta(\mathrm{ppm})=0.98(\mathrm{~s}, 6 \mathrm{H}, 2 \mathrm{xMe}), 1.65$ (s, 3H, Me), 1.7-1.9 (m, 2H, H-5'), 2.1-2.2 (3s, $12 \mathrm{H}, 4 x \mathrm{xAc}), 2.3$ (s, 3H, $\left.\mathrm{COCH}_{3}\right), 3.96$ (m, 1H, H-5' '), 4.1-4.2 (m, 3H, H-6', H-1' '), 4.36 (m, 1H, H-4'), 4.96 (dd, 1H, J1", ," =9.5 Hz, H-2' '), 5.20 (m, 1H, H-4' '), 5.54 (s, 1H, H-3'), 5.70 (m, 1H, H-3'’), 6.6 (ABq, 2H, J3,4=15.7 Hz, H-3, H4). ${ }^{13} \mathrm{C}-\mathrm{NMR}(50 \mathrm{MHz}): \delta(\mathrm{ppm})=21.2(\mathrm{Me}), 24.6,24.7(2 \mathrm{Me}), 28.7(\mathrm{C}-1), 38.5(\mathrm{C}-6), 40.7$ (C-5'), 63.5 (C-6') ), 67.5, 68.5, 70.5, 73.5, 73.6 (C-1', C-2'’- C-5'’), 97.4 (C-1'’), 126.8 (C-2'), 130.7 (C-3), 138.3 (C-2'), 147.6 (C-4) 170.0-171.1 (4 C=O), 198.2 (C-2). Anal. Calcd for $\mathrm{C}_{27} \mathrm{H}_{38} \mathrm{O}_{12}$ : C, 58.47; H, 6.91. Found: C, 58.34; H, 6.79\%.

\section{E-[4'-[( $\beta$-D-Glucopyranosyl)oxy]-1'-hydroxy-2',6',6'-trimethylcyclohex-2-enyl]but-3-en-2-} one (6) (mixture of diastereoisomers). A solution of the acetate 5 (830 $\mathrm{mg}, 1.5 \mathrm{mmol})$ in dry methanol $(50 \mathrm{ml})$ was cooled to $-20^{\circ} \mathrm{C}$ and then $\mathrm{NaOMe}(0.1 \mathrm{ml}, 1 \mathrm{M}$ in methanol) was added. The mixture was kept at $-20^{\circ} \mathrm{C}$ for $5 \mathrm{~h}$. and was then neutralized by addition of ion exchange resin (Ionenaustauscher I, Merck). After filtration, the filtrate was evaporated to afford 6 (510 $\mathrm{mg}, 88 \%)$ as a white foam. ${ }^{1} \mathrm{H}-\mathrm{NMR}\left(\mathrm{CDCl}_{3}, 200 \mathrm{MHz}\right): \delta(\mathrm{ppm})=0.98(\mathrm{~s}, 6 \mathrm{H}, 2 \mathrm{Me}), 1.67(\mathrm{~s}$, 3H, Me), 1.7-1.9 (m, 2H, H-5'), 2.34 (s, 3H, $\left.\mathrm{COCH}_{3}\right), 3.3-3.9$ (2m, 6H, H-2', H-6') 4.26 (m, 2H, H-4', H-1'’) 5.67 (s, 1H, H-3'), 6.60 (ABq, 2H, J3,4=15.8 Hz, H-3, H-4). ${ }^{13} \mathrm{C}-\mathrm{NMR}(50$ MHz): $\delta(\mathrm{ppm})=18.7(\mathrm{Me}), 24.0,24.3$ (2 Me), 26.9 (C-1), 38.5 (C-6'), 41.5 (C-5'), 61.4 (C-6'), 64.9 (C-6'), 70.6, 71.1, 71.9, 74.5 (C-1', C-2'’-C-5'’), 91.1 (C-1'’), 128.5 (C-3'), 130.3 (C-3), 136.6 (C-2'), 151.2 (C-4) 201.5 (C-2). Anal. Calcd for $\mathrm{C}_{19} \mathrm{H}_{30} \mathrm{O}_{8}$ : C, 59.05; H, 7.82. Found: C, $58.45 ; \mathrm{H}, 7.67 \%$. 


\section{References}

1. Paul, N.; Séquin, U.; Walter, A. Helv. Chim. Acta 1990, 73, 578.

2. Mamun, M. I. R.; Nahar, N.; Azad Khan, Ali., L.; Rokeya, B.; Lunfgren, L.; Andersson, R.; Reutrakul, V. ASOMPS X 2000, Book of Abstracts 2000, p. 73.

3. Busch, J.; Grether, Y.; Ochs, D.; Séquin, U. J. Nat. Prod. 1998, 61, 591.

4. Findleay, J. A.; MacKay, W. D. Canad. J. Chem. 1971, 49, 2369.

5. Kato, T.; Kondo, H. Bull. Chem. Soc. Jpn. 1981, 54, 1573.

6. Pasto, D. J.; Taylor, R. T. Org. React. (N.Y.) 1991, 40, 91.

7. Dai, J.; Krohn, K.; Gehle, D.; Kock, I.; Flörke, U.; Aust, H.-J.; Draeger, S.; Schulz, B.; Rheinheimer Eur. J. Org. Chem. 2005, 4009. 